\title{
Determination of NP Fertilizer Rates and Plant Population Density on Yield and Yield Related Parameters of Quality Protein Maize (Zea mays L.) in Southwestern Ethiopia
}

\author{
Sisay Gurmu \\ Jimma Agricultural Research Center, Jimma, Ethiopia. \\ Email:sis.sis1835@gmail.com
}

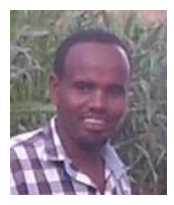

\begin{abstract}
Field studies were conducted in 2015 and 2016 under rain fed conditions in south western Ethiopia, Jimma zone to determine optimum plant population density and NP fertilizer on Maize. The experiment had four NP fertilizer rates; 69/52, 92/69, 115/86, and 138/104 N/ $\mathrm{P}_{2} \mathrm{O}_{5} \mathrm{~kg} \mathrm{ha}^{-1}$ and four plant population density; 44,444.(75cm*30cm), 53,333(75cm*25cm), 66,666 $(75 \mathrm{~cm} * 20 \mathrm{~cm})$ and $88,888(75 \mathrm{~cm} * 15 \mathrm{~cm})$ plants per hectare. Each treatment was assigned to each plot in split plot design. Grain yield and above ground biomass significantly increased as plant populations and NP fertilizer rates increased. The number of ears per plant was significantly decreased as plant population density increased and increased with the increased rate of NP fertilizer. The greater lodging was recorded in 2015 cropping season when compared with that of 2016 cropping season. The highest grain yield $8752 \mathrm{~kg} \mathrm{ha}^{-1}$ and above ground biomass 18.33 ton ha-1 were recorded from $138 / 104 \mathrm{~N} / \mathrm{P}_{2} \mathrm{O}_{5}$ fertilizer. Regarding plant population density the highest grain yield $9401 \mathrm{~kg}$ $\mathrm{ha}^{-1}$ and above ground biomass 19.90 ton ha- ${ }^{-1}$ were recorded from 88,888 plants ha-1 $\left(75 \mathrm{~cm}^{*} 15 \mathrm{~cm}\right)$. The highest net benefit 30,669ETB ha ${ }^{-1}$ with highest MRR $164 \%$ was recorded from 115/86 $\mathrm{N} / \mathrm{P}_{2} \mathrm{O}_{5} \mathrm{~kg} \mathrm{ha}{ }^{-1}$. Concerning plant population density the highest net benefit 36,705 ETB ha-1 with acceptable MRR $585 \%$ was obtained from 88,888 plants $\mathrm{ha}^{-1}\left(75^{*} 15 \mathrm{~cm}\right)$. Therefore, plant population density 88,888 plants ha-1 $\left(75^{*} 15 \mathrm{~cm}\right.$ a plant hill-1 or $75 \times 30 \mathrm{~cm}$ two plants hill-1) with $\mathrm{N} / \mathrm{P}_{2} \mathrm{O}_{5}$ fertilizer rate of $115 / 86 \mathrm{~kg} \mathrm{ha}{ }^{-1}$ can be advisable for farmers in the study area and adjacent woredas' with similar agro-ecologies.
\end{abstract}

Keywords: Grain yield, Plant population density, Quality protein maize and fertilizer.

Citation | Sisay Gurmu (2020). Determination of NP Fertilizer Rates and Plant Population Density on Yield and Yield Related Parameters of Quality Protein Maize (Zea mays L.) in Southwestern Ethiopia. Agriculture and Food Sciences Research, 7(1): 69-78.

History:

ed: 5 February 2020

Revised: 10 March 2020

Accepted: 13 April 2020

Published: 15 May 2020

Licensed: This work is licensed under a Creative Commons

Attribution 3.0 License (co)

Publisher: Asian Online Journal Publishing Group
Funding: The research was funded by Ethiopia Institute of Agricultural Research

Competing Interests: The author declares that there are no conflicts of interests regarding the publication of this paper.

Transparency: The author confirms that the manuscript is an honest, Transparency: The author confirms that the manuscript is an honest,
accurate, and transparent account of the study was reported; that no vital features of the study have been omitted; and that any discrepancies from the features of the study have been omitted;
study as planned have been explained.

Ethical: This study follows all ethical practices during writing.

\section{Contents}

1. Introduction

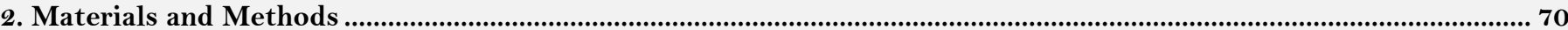

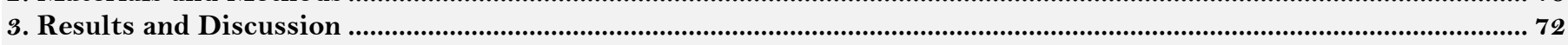

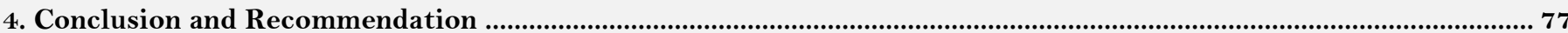

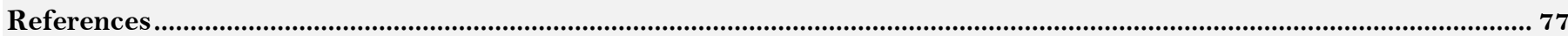




\section{Contribution of this paper to the literature}

This research study can find answers to things that are unknown around maize planting, filling gaps in knowledge and changing the way that maize agronomist works in general.

\section{Introduction}

Globally, maize (Zea mays L.) is among the leading cereals in production along with rice and wheat. In Africa, Ethiopia is the third largest maize producer next to Nigeria and Egypt [1]. Maize ranks second after teff in area coverage and first in total production in Ethiopia [2]. In 2016/17 the maize crop area and grain production in Ethiopia was 2,135,572 ha and 7, 8471,175 ton, respectively with productivity of $3675 \mathrm{~kg} \mathrm{ha}^{-1}$ [Q]. Normal maize grain has greater nutritional value as it contains $72 \%$ carbohydrate, $8.8 \%$ protein, $2.15 \%$ fiber and $2.33 \%$ ash [ $[3]$. It is a good source of carbohydrates, fat, protein and some important vitamins (B6, A and E) and minerals (magnesium, potassium and phosphorus), but deficient in essential amino acids viz., lysine and tryptophan that reduces its biological value [4]. The amount of these deficient amino acids has been increased by incorporating opaque-2 gene in quality protein maize $(\mathrm{QPM})$ [5]. It produces $70-100 \%$ more of lysine and tryptophan than the most modern varieties of tropical maize [6].

Insufficient application of nutrients and poor soil management, along with harsh climatic conditions and other factors, have contributed to the degradation of soils including soil fertility depletion in developing countries, especially in SSA [7]. Poor soil fertility is one of the principal factors that limit maize productivity in maize growing areas of Ethiopia [8]. Degradation of soil physico-chemical properties, soil acidity with high P sorption and soil nutrient depletion due to low chemical fertilizer use by most small-holder farmers who cannot afford the expensive fertilizers leads to declining in maize production in SSA [9].

Among plant nutrients nitrogen is a vitally important, a major yield determining nutrient and its availability in sufficient quantity throughout the growing season is essential for optimum maize growth [10]. It is a component of protein, nucleic acids and other compounds essential for plant growth process [11]. Whereas phosphorus is the second most important nutrient element (after nitrogen) limiting agricultural production [10]. It is used for growth, utilization of sugar and starch, photosynthesis, metabolic process which leads to higher yield of the crop $[12]$.

Maize is commonly planted in rows of varying spaces; less effort has been made to plant at optimum densities to maximize its productivity in different agro-ecologies of Ethiopia. Summaries of earlier results from different studies on maize plant population densities indicate that better yields were obtained at planting density in range of 6-7.5 plants $\mathrm{m}^{-2}$ [13]. It is being observed that medium and early maize varieties in humid lowlands and low moisture stress area found to be varied in structure and leaf arrangements from known normal maize varieties. These variations in morphology may lead to different planting density to reach at their at maximum yield potentials.

Plant population density has a significant impact on growth and yield of crops, including maize, a popular $\mathrm{C} 4$ cereal crop. Therefore, understanding how plants regulate their growth in response to plant population densities has problems, such as determination of optimal sowing density. Increased plant populations could lead to increased yields under optimal climatic and management conditions due to greater number of smaller cobs per unit area [14].

Hence, for further dissemination and adoption of QPM hybrid there is a need to understand its performance with various agronomic management practices, of which nutrient management and plant stand are vital in influencing the growth and yield of the crop. Hence, this study was initiated with the objective to study the effect of plant population density and NP fertilizer on the growth and yield of maize.

\section{Materials and Methods}

\subsection{Description of the Study Area}

The research activity was performed on farmers' field in Omonadawareda (Nada-SadechaKebele) of Jimma Zone, South western Ethiopia in main cropping seasons (mid May up to early November) of 2015 and 2016 Figure 1. This location is foundon latitude $7^{\circ} 36^{\prime} \mathrm{N}$ and longitude $37^{\circ} 15^{\prime} \mathrm{E}$ and laid at an altitude of 1764 m.a.s.l. Ten years average minimum and maximum temperature is $8^{\circ} \mathrm{C}$ and $28^{\circ} \mathrm{C}$ respectively and reliably receives annual average rainfall of $1200 \mathrm{~mm}$ with agro-ecology characterized by humid mid altitude. The farming system of the study site is cereal crops dominated with maize, teff and sorghum also has warm and cold climate, also convenient topography which is very suitable for all agricultural practices. The soil type of the experimental area was Eutric-nitisols (reddish brown).
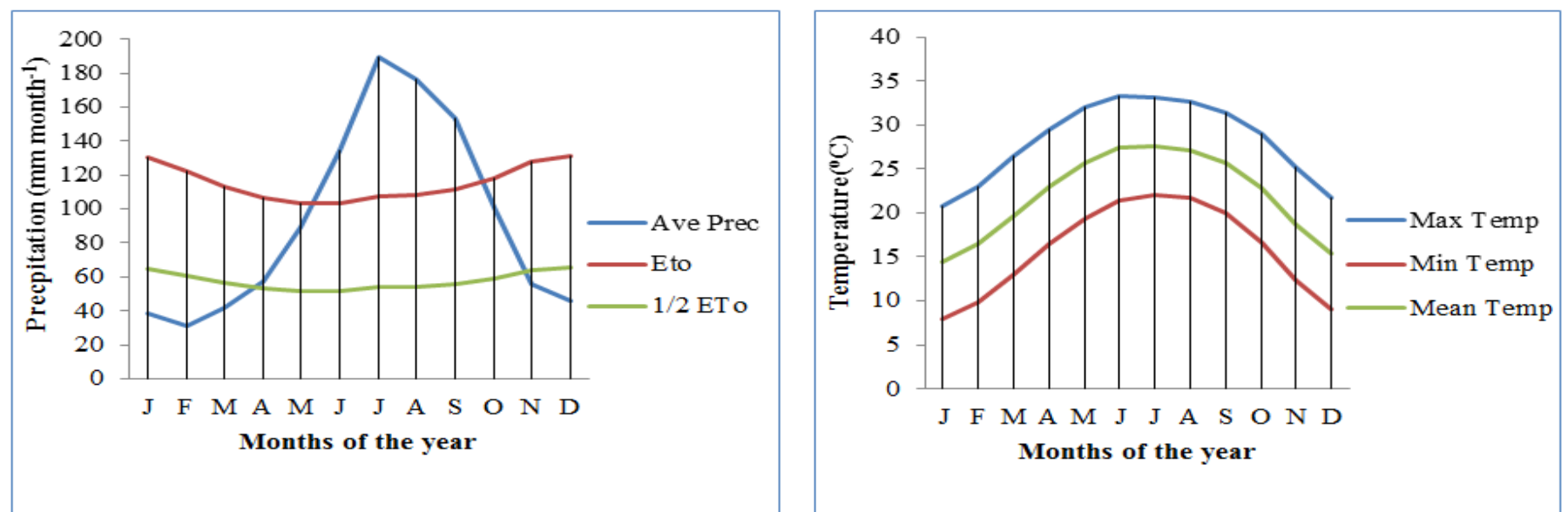

Figure-1. Decadal time scale (2007-2016) of Precipitation, ETo, 1/2 ETo, maximum and minimum temperature at Jimma, Omonadaworeda. 


\subsection{Soil Physico-Chemical Properties}

The soil of the experimental field was characterized for selected physico-chemical properties before the application of the treatments Table 1 .The average soil $\mathrm{pH}$ of the trial site was 5.13 , which was strongly acidic [15] and ideal for the production of most field crops. The $\mathrm{pH}$ of the soil affects maize growth by suppressing the root development and reducing availability of macronutrients to plants especially phosphorus [16]. The soil total $\mathrm{N}$ was $0.19 \%$.These was found to be a medium rate for crop growth and development [17]. The OC content of experimental area was $2.08 \%$ and it was found medium rate for crop growth [18]. The Bray II extractable available $\mathrm{P}$ was $6.17 \mathrm{mg} \mathrm{kg}{ }^{-1}$ which is below the critical level $\left(8 \mathrm{mg} \mathrm{kg}^{-1}\right)$ for most crop plants as described by Tekalign and Haque [19]Table 1.

Table-1.Selected physico-chemical properties of the soil of the experimental sites before planting.

\begin{tabular}{|c|c|c|c|c|}
\hline Soil characters & Values & Rating & Reference & Method of analysis \\
\hline $\mathrm{pH}(1: 2.5)$ & 5.13 & Strongly acidic & Batjes $[15]$ & 1:2.5 ratio water method \\
\hline $\mathrm{Av} \mathrm{P}\left(\mathrm{mg} \mathrm{kg}^{-1}\right)$ & 6.17 & Low & $\begin{array}{l}\text { Tekalign and Haque } \\
{[19]}\end{array}$ & Bray II method [20] \\
\hline $\mathrm{TN}(\%)$ & 0.19 & Medium & Berhanu [17] & Kjeldahl method [21] \\
\hline $\mathrm{OC}(\%)$ & 2.08 & medium & Tekalign [18] & $\begin{array}{l}\text { Walkley and Black method } \\
{[22]}\end{array}$ \\
\hline C:N ratio & 11.05 & Medium & Brady and Weil [23] & \\
\hline $\mathrm{OM}(\%)$ & 3.58 & High & Berhanu $[17]$ & \\
\hline
\end{tabular}

Note: Where $\mathrm{pH}=$ Hydrogen ion concentration, $\mathrm{OC}=$ Organic Carbon, $\mathrm{TN}=$ Total Nitrogen, Av. $\mathrm{P}=$ Available Phosphorous, OM=Organic Matter

Values are the means of duplicated samples.

\subsection{Experimental Treatments and Procedures}

The experimental field was ploughed and prepared following the conventional tillage practice before planting. The land was leveled using manual power before the field layout was made. The maize was planted during mid May and harvested early November of each year. Two maize seeds were planted per hill and then thinned to one plant per hill after good establishment of seedlings so as to maintain a single healthy plant per hill. There were four NP fertilizer rates; 69/52, 92/69, 115/86, and $138 / 104 \mathrm{~kg} / \mathrm{ha} \mathrm{N} / \mathrm{P}_{2} \mathrm{O}_{5}$ and four plant population density; 44,444, $53,333,66,666$, and 88,888 plants per hectare. The experimental plot size was $22.95 \mathrm{~m}^{2}(4.5 \mathrm{~m} \mathrm{x} 5.1 \mathrm{~m})$ for each treatment. The split plot design with three replications was used that plant population densities in main plot and fertilizer rates in subplots.

Nitrogen and phosphorus fertilizers were calculated as per rates given above and applied per area base. To increase the nitrogen use efficiency, it was split in three equal rates and applied at planting time, knee height and flag leaf initiation stages. All other agronomic practices were applied uniformly to all experimental plots in the study area.

\subsection{Description of the Experimental Materials}

Medium maturing maize variety BHQPY545 was used in the present study. It was released by Bako Agricultural Research Centre through the National Maize Research Program in 2008. It performs well in agroecology of 1000-2000 m.a.s.l with rainfall of 1000-1200 mm. It can give 8.0-9.5 and 5.5-6.5 t ha-1 grain yields under on-station and on-farm experiments, respectively. It was moderately tolerant to rust, blight and gray leaf spot with maturity date of 138.

\subsection{Data Collected}

2.5.1. Plant Height $(\mathrm{cm})$

It was measured at ground level to terminal stem using measuring stick at the point where the tassel starts branching from six randomly selected plants.

\subsubsection{Number of Earper Plant}

It was obtained by counting total number of ears in each plot and divided to total number of plant stand harvested.

\subsubsection{Grain Field $\left(\mathrm{kg} \mathrm{ha}^{-1}\right)$}

Grain yield per plot was recorded using electronic balance and then adjusted to $12.5 \%$ moisture and converted to hectare basis.

\subsubsection{Above Ground Biomass (kg ha-1)}

All above ground biomass was harvested from net plot and weighted, ears were removed and weighted separately, six plants were selected, chopped and oven dried till get uniform weight.

\subsubsection{Lodging Percent}

It was obtained by counting the total number of stalk and root lodging in each plot and divided to the total number of plant stand at harvesting.

\subsubsection{Harvest Index}

Was calculated as the ratio of grain yield to above ground biomass yield on dry weight basis [24]. HI(\%) = Economic yield (kg/ha) $\frac{\text { Total biological yield }(\mathrm{kg} / \mathrm{ha})}{\mathrm{N}} \mathrm{100}$ 


\subsection{Data Analysis}

Analysis of variance (ANOVA) for all collected data was computed using SAS version 9.3 statistical software. Whenever the ANOVA results showed the significant differences between sources of variation, the means were compared using least significant difference.

\subsection{Partial Budget Analysis}

Partial budget analysis was performed to investigate the economic feasibility of the treatments and assess the costs and benefits associated with different treatments of chemical fertilizers and plant population density of the seed rates. The partial budget technique as described by CIMMYT [25] was applied. The partial budget analysis was done using the prevailing market prices for inputs at planting and for outputs at the time the crop was harvested. All costs and benefits were calculated on a per hectare basis in Ethiopian Birr (ETB). The inputs and/or concepts used in the partial budget analysis were the mean grain yield of each treatment, the gross field benefit $(\mathrm{GFB}) \mathrm{ha}^{-1}$ (i.e., the product of field price and the mean yield for each treatment), the field price of chemical fertilizers and urea $\mathrm{kg}^{-1}$ (the nutrient cost plus the cost of transportation from the point of sale to the farm), cost of labor spent on seed purchase and planting, the total costs that varied (TVC) which included the sum of field costs of fertilizers and their application, and seed purchase and planting.

The net benefit (NB) was calculated as the difference between the GFB and the TVC. The marginal rate of return (MRR \%) were also calculated. To obtain an estimate of these returns, the MRR (\%) was calculated as changes in NB divided by changes in cost. Thus, a minimum acceptable MRR of $100 \%$ was used; indicating for every one ETB expended there is a return of one ETB for a given variable input [25] which is suggested to be realistic. This enables the farmer to make recommendations from marginal analysis. The dominance analysis procedure as detailed in CIMMYT [25] was used to select potentially profitable treatments from the range that was tested. Sensitivity analysis for different interventions was also carried out to test the recommendation made for its ability to withstand price changes. Sensitivity analysis simply implied redoing marginal analysis with the alternative prices. Through sensitivity analysis, maximum acceptable field price of an input was calculated with the minimum rate of return as described by Shah, et al. [26].

\section{Results and Discussion}

The effect of different rates of NP fertilizer and plant population density on yield and yield related parameters of QPM maize variety and cost benefit analysis were presented and discussed as follows.It has been observed that medium maturing maize variety like BHQPY545 vary in structure and leaf arrangements from other late maturing maize varieties. These variations in morphology may lead to different planting density to reach the maximum yield potentials.

Table-2. Mean square from combined analysis of the effects of NP fertilizer rates and plant population density on growth, yield attributes and yield of QPM maize during 2015 and 2016 cropping seasons at Omonadaworeda, Jimma zone southwestern Ethiopia.

\begin{tabular}{|c|c|c|c|c|c|c|c|c|c|}
\hline \multicolumn{10}{|c|}{ Mean square for source of variation } \\
\hline Parameter & Year $(1)$ & $\begin{array}{ll}\text { Intra } & \text { row } \\
(3) & \end{array}$ & $\begin{array}{l}\text { Year*Intra } \\
\text { row (3) }\end{array}$ & $\begin{array}{ll}\text { Year } & x \\
\text { NP (3) } & \end{array}$ & NP (3) & $\begin{array}{l}\text { Intra row } \\
x \text { NP }(9)\end{array}$ & $\begin{array}{l}\text { Year } \quad x \\
\text { Intra row } \\
x \text { NP }(9)\end{array}$ & $\begin{array}{l}\text { Error a } \\
(6)\end{array}$ & $\begin{array}{l}\text { Error } \\
\text { b } \\
(24) \\
\end{array}$ \\
\hline $\begin{array}{l}\text { Plant } \\
\text { height }(\mathrm{cm})\end{array}$ & $41242.7^{* *}$ & $823.5972^{*}$ & $88.39583^{\text {ns }}$ & $52.6875^{\mathrm{ns}}$ & $2132.5^{* *}$ & $119.44^{\mathrm{ns}}$ & $209.340^{\text {ns }}$ & 238.079 & 88.396 \\
\hline Ears per plant & $1.3085^{* *}$ & $0.98015^{* *}$ & $0.02850^{\mathrm{ns}}$ & $0.02554^{\mathrm{ns}}$ & $0.23307^{* *}$ & $0.02496^{\mathrm{ns}}$ & $0.03228^{\mathrm{ns}}$ & 0.0522 & 0.0285 \\
\hline Lodging $\%$ & $4773.8^{* * *}$ & $431.436^{\mathrm{ns}}$ & $457.346^{\mathrm{ns}}$ & $544.517^{\mathrm{ns}}$ & $93.628^{\mathrm{ns}}$ & $56.884^{\mathrm{ns}}$ & $94.989^{\mathrm{ns}}$ & 82.85 & 89.85 \\
\hline $\begin{array}{l}\text { Grain yield } \\
\left(\mathrm{kg} \mathrm{ha}^{-1}\right)\end{array}$ & $112165917^{* * *}$ & $48126018^{* *}$ & $1241199^{\text {ns }}$ & $1692656^{\mathrm{ns}}$ & $17101704^{* *}$ & $1535100^{\text {ns }}$ & $1459915^{\mathrm{ns}}$ & 2916763 & $\begin{array}{l}12411 \\
98 \\
\end{array}$ \\
\hline $\mathrm{AGB}\left(\mathrm{t} \mathrm{ha}^{-1}\right)$ & $402.058^{* *}$ & $219.1591^{* *}$ & $0.5320^{\mathrm{ns}}$ & $7.3594^{\mathrm{ns}}$ & $54.8910^{* *}$ & $6.2721^{\mathrm{ns}}$ & $5.2058^{\mathrm{ns}}$ & 8.539 & 0.532 \\
\hline Harvest index & $0.0011^{\mathrm{ns}}$ & $0.000973^{\text {ns }}$ & $0.0051^{\text {ns }}$ & $0.00011^{\mathrm{ns}}$ & $0.001581^{\mathrm{ns}}$ & $\begin{array}{l}0.002343^{n} \\
s\end{array}$ & $0.0017^{\mathrm{ns}}$ & 0.0026 & 0.0051 \\
\hline
\end{tabular}

Note: *Numbers in parenthesis $=$ Degrees of freedom; *= Significant $(\mathrm{P} \leq 0.05) ; * *$ highly significant $(\mathrm{p}<0.01)$ difference; AGB $=$ Aboveground biomass; ha $=$ Hectare

The homogeneity test of the error variances for years indicated that the error variance was homogenous and hence combined analysis of variance was conducted. Over year combined analysis effects of NP fertilizer rates and plant population density didn't show significant $(\mathrm{P}>0.05)$ interaction effect on plant height, ears per plant, lodging percent, grain yield, aboveground biomass and HI. Plant height was significantly $(\mathrm{P}<0.05)$ influenced by plant population density and highly significantly $(\mathrm{P}<0.01)$ influenced by NP fertilizer and year. Whereas ears per plant, grain yield and above ground biomass were highly significantly $(\mathrm{P}<0.01)$ influenced by $\mathrm{NP}$ fertilizer rates, plant population density and year. However, lodging percent and harvest index were not significantly $(\mathrm{P}>0.05)$ affected by both NP fertilizer rates and plant population density, but lodging percent was highly significantly $(\mathrm{P}<0.01)$ affected by the year difference Table 2 .

\subsection{Effect of NP Fertilizer and Plant Population Density on Growth Parameters \\ 3.1.1. Plant Height}

At Omonada woreda Jimma zone, medium maturing maize hybrid (HBQPY545) had exhibited vigorous growth performances and resulted in good response to both NP fertilizer and plant population density. The mean significant higher plant height was recorded in 2016 main cropping season. Numerically, the longer plant height $(247.0 \mathrm{~cm})$ was recorded by plant population density of 88,888 plants ha $^{-1}\left(75^{*} 15 \mathrm{~cm}\right)$ but its effect was not statistically significant different from plant population density of 53,333 and 66,666 plants ha ${ }^{-1}$. While the shorter plant height $(237.1 \mathrm{~cm})$ was recorded by 44,444 plants ha $^{-1}\left(75^{*} 30 \mathrm{~cm}\right)$ Table 3 . These results indicated as plant population increased the plant height also increased and vice versa. The plant height was increased by $4.2 \%$ at the highest plant population density as compared to the lowest plant population density.Highest plant height in closer intra row spacing might be due to the presence of higher competition for sun light, crowding effect of the plant and 
other resources that decrease in the stem diameter and number of green leaves. Earlier results explained that the number of plants increased in a given area, the competition among the plants for nutrients uptake and sunlight interception also increased [27]. These finding is in agreement with Hassan [28] who revealed that plant height increased with increasing plant density from 47600 to 71400 plants ha-1.

Regarding the effect of NP fertilizer rates the longer plant height $(250.5 \mathrm{~cm})$ was recorded by $138 / 104 \mathrm{~kg} \mathrm{ha}^{-1}$ $\mathrm{N} / \mathrm{P}_{2} \mathrm{O}_{5}$ fertilizer. But its effect was statistically at par with $115 / 86 \mathrm{~kg} \mathrm{ha}^{-1} \mathrm{~N} / \mathrm{P}_{2} \mathrm{O}_{5}$ fertilizer, while the shorter plant height (0.90) was recorded from $69 / 52 \mathrm{~kg} \mathrm{ha}{ }^{-1} \mathrm{~N} / \mathrm{P}_{2} \mathrm{O}_{5}$ fertilizer Table 3. The results indicated that as NP fertilizer increased the plant height was also increased and vice versa. Application of 138/104 kg ha-1 N/ $\mathrm{P}_{2} \mathrm{O}_{5}$ fertilizer increased plant height by $6.7 \%$ over $69 / 52 \mathrm{~kg} \mathrm{ha}{ }^{-1} \mathrm{~N} / \mathrm{P}_{2} \mathrm{O}_{5}$ fertilizer. The increase in plant height with increasing rate of NP fertilizer could be due to their major effect in crop growth and development. Nitrogen is considered as one of the major limiting nutrients in plant growth and adequate supply of it promotes the formation of chlorophyll which in turn resulted in higher photosynthetic activity, vigorous vegetative growth and taller plants. Whereas phosphorous is required for shoot and root development where metabolism is high and cell division is rapid [29]. These results were in line with the findings of Adekayode and Ogunkoya [30] who explained that there was very high significant difference in maize plant height in plots treated with higher fertilizer compared with nil application. Also Kumar, et al. [31] reported that growth and yield of maize plants in terms of plant height varied significantly due to various fertility levels. He reported the highest plant height was recorded from application of 100\% NPK (120N:26.2P:33.2K) with 10 ton FYM ha-1 over control.

\subsection{Effect of NP Fertilizer and Plant Population Density on Yield and Yield Related Parameters 3.2.1. Number of Ears per Plant}

Number of ear per plant was determined by prolific ability of the BHQPY 545 maize variety as described by Adefris, et al. [32] and the growth behavior of the crop which is dependent upon management practices and edaphic and climatic factors. The number of ears per plant was higher (1.43) during 2016 main cropping season as compared with 2015 cropping season. The maximum number of ear per plant (1.50) was recorded from 44,444 plants ha-1 $\left(75^{*} 30 \mathrm{~cm}\right)$ which was statistically at par with 53,333 plants $^{-1} \mathrm{a}^{-1}\left(75^{*} 25 \mathrm{~cm}\right)$ while the minimum number of ears per plant $(1.17)$ was recorded from 88,888 plants ha-1 $\left(75^{*} 15 \mathrm{~cm}\right)$ Figure 2 . These results indicated as plant population density increased number of ears per plant linearly decreased and vice versa. The number of ears per plant was increased by $28.2 \%$ at the lowest plant population density (44,444 plants ha' $\left.{ }^{-1}\right)$ as compared to the highest plant population density $\left(88,888\right.$ plants $\left.\mathrm{ha}^{-1}\right)$. This might be due to in the closest spacing there is high inter stem competition to nutrients and sun light so, it caused lack of nutrient for each plant and consequently compelling the plants to undergo less reproductive growth. These finding are in agreement with Hashemi-Dezfouli and Herbert [33] who reported a significantly higher number of ear per plant at lower plant density as compared to higher plant density.

Concerning the response of number of ears per plant to NP fertilizer rates the maximum number of ears per plant (1.41) was recorded from 138/104 kg ha-1 N/P $\mathrm{P}_{2} \mathrm{O}_{5}$ fertilizer. But its effect was statistically at par with 92/69 and $115 / 86 \mathrm{~kg} \mathrm{ha}^{-1} \mathrm{~N} / \mathrm{P}_{2} \mathrm{O}_{5}$ fertilizer, while the minimum number of ears per plant (1.26) was recorded from 69/52 $\mathrm{kg} \mathrm{ha}{ }^{-1} \mathrm{~N} / \mathrm{P}_{2} \mathrm{O}_{5}$ fertilizer Figure 2. These result indicated as $\mathrm{NP}$ fertilizer rate increased to $138 / 104 \mathrm{~kg} \mathrm{ha} \mathrm{h}^{-1} \mathrm{~N} / \mathrm{P}_{2} \mathrm{O}_{5}$ fertilizer, the number of ears per plant was increased and vice versa. Application of 138/104 kg ha-1 $\mathrm{N} / \mathrm{P}_{2} \mathrm{O}_{5}$ fertilizer increased number of ears per plant by $11.9 \%$ over application of $69 / 52 \mathrm{~kg} \mathrm{ha}^{-1} \mathrm{~N} / \mathrm{P}_{2} \mathrm{O}_{5}$ fertilizer. The improvement of the soil conditions or enrichment with nutrients due to soil-added materials might be responsible for better cob production under plots treated with higher NP fertilizer. Nitrogen can trigger vegetative growth and development and it is an integral part of chlorophyll, which is the primary absorber of light energy needed for photosynthesis. These results were in line with the result of Singh and Nepalia [34] who reported the application of higher dose of chemical fertilizer improved the number of cobs plant ${ }^{-1}$ in QPM hybrid significantly over the lower nutrient application.
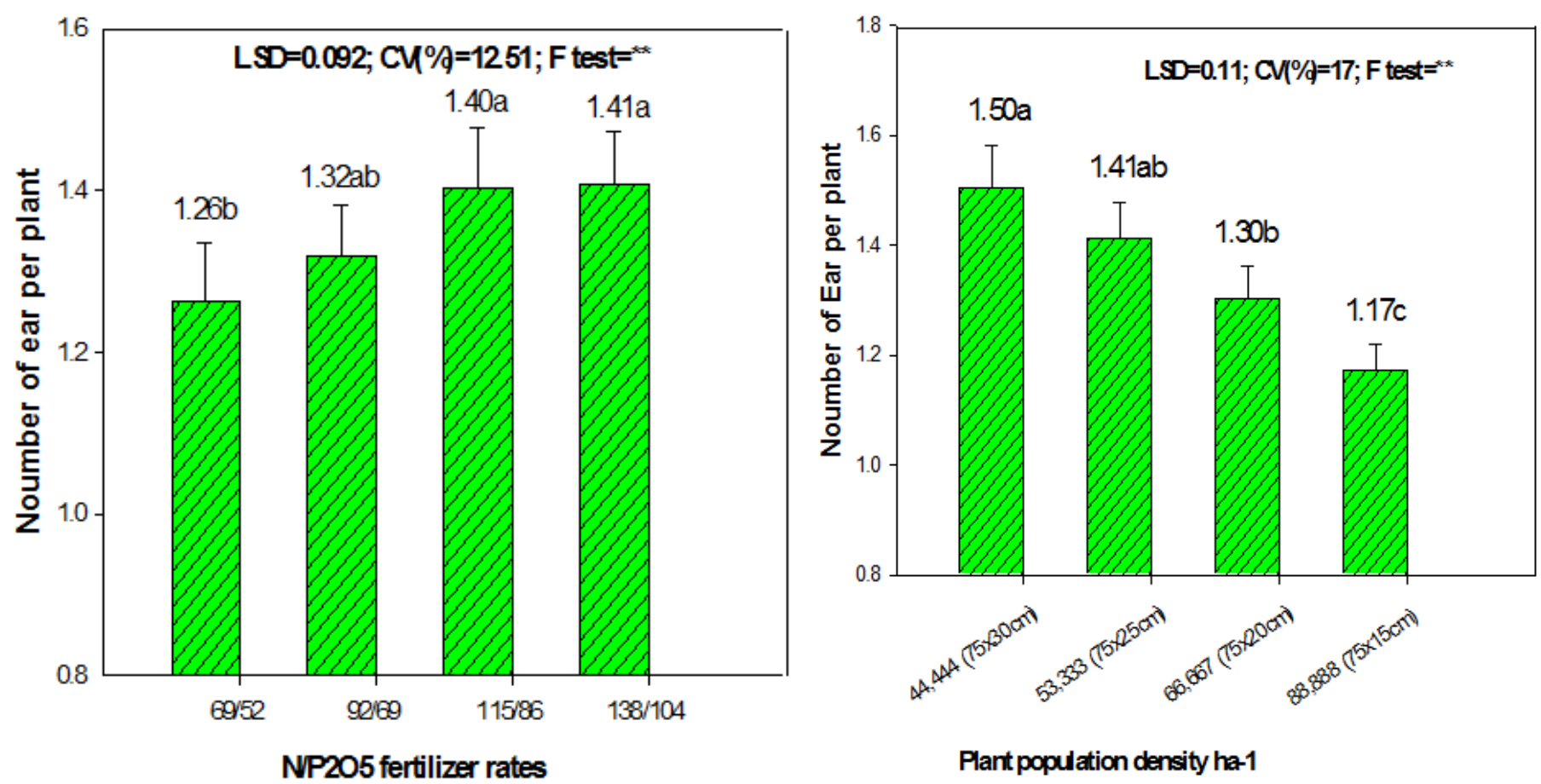


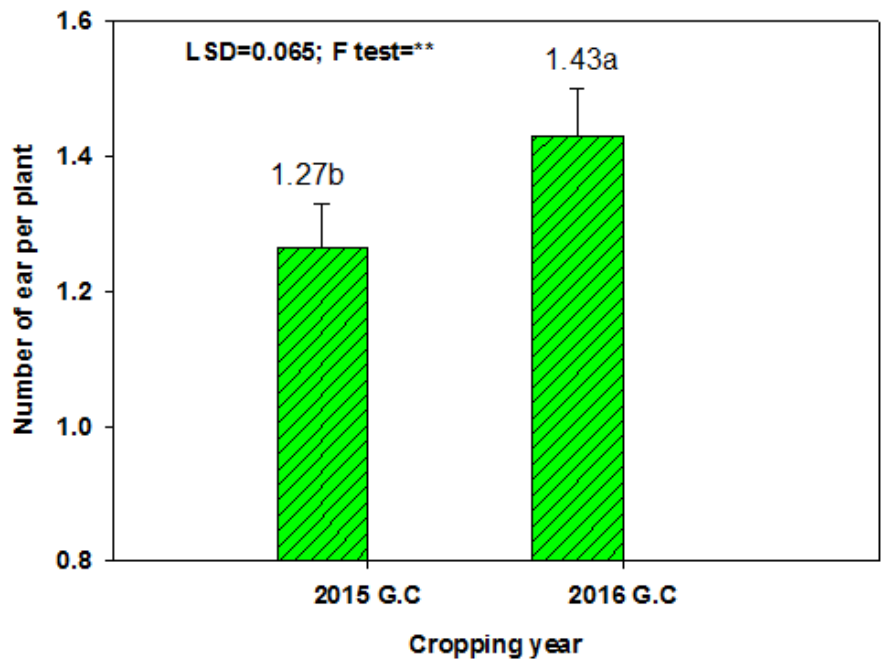

Figure-2.Effect of NP fertilizer and plant population density on number of ear per plant at Jimma, Omonadaworeda in 2015 and 2016 cropping seasons.

\subsubsection{Lodging Percent}

During 2015 main cropping season the lodging percent of QPM maize variety was higher than during 2016 cropping season. It was not significantly $(\mathrm{P}>0.05)$ affected by both NP fertilizer rates and plant population density Table 2.

\subsubsection{Grain Yield}

Hybrid QPM maize BHQPY545 had exhibited vigorous growth performances and resulted in good response to NP fertilizers and plant population density in season 2015 and significant increase in grain yield was recorded Table 3. Over season mean indicated, the higher plant population density $\left(88,888\right.$ plant $\left.\mathrm{ha}^{-1}\right)$ gave higher grain yield $\left(9401.2 \mathrm{~kg} \mathrm{ha}{ }^{-1}\right.$ ) while the lower grain yield (7046.0 $\mathrm{kg} \mathrm{ha}^{-1}$ ) was recorded from 44,444 plants ha-1 $\left(75^{*} 30 \mathrm{~cm}\right)$ Table 3 . The result indicated as the plant population density increased the grain yield of QPM maize variety linearly increased and vice versa. The grain yield of the crop was increased by $33.4 \%$ at the highest plant population density $\left(88,888\right.$ plants ha-1) as compared to lowest plant population density $\left(44,444\right.$ plants ha- $\left.^{-1}\right)$ and this is due to low plant population harvested $\mathrm{ha}^{-1}$ in wider spacing intra row spacing. Thus, balanced growth and development of plants need optimum plant density because optimum density enables plants efficient utilization of available nutrients, soil water and better light interception coupled with other growth influencing factors. Therefore, results of this contradicted the previous recommendation $75 \mathrm{x} 30 \mathrm{~cm}$ inter and intra row spacing resulted in the production of grain yield. These results were supported by Emam [35] who verified that kernels ear-1 and kernels row ear-1 were the most important yield adjustment components in response to plant population density in maize. These finding was in agreement with Farnham [36] who reported that maize grain yield increased as plant density increased from 59,000 to 89,000 plant ha-1.

Regarding the effect of NP fertilizer rates $138 / 110 \mathrm{~kg} \mathrm{ha}{ }^{-1} \mathrm{~N} / \mathrm{P}_{2} \mathrm{O}_{5}$ fertilizergave significantly higher grain yield of $8751.6 \mathrm{~kg} \mathrm{ha}{ }^{-1}$ which was statically at par with $115 / 86 \mathrm{~kg} \mathrm{ha}^{-1} \mathrm{~N} / \mathrm{P}_{2} \mathrm{O}_{5}$ fertilizerrate while, the lowest grain yield $7442.2 \mathrm{~kg} \mathrm{ha}{ }^{-1}$ was recorded from $69 / 52 \mathrm{~kg} \mathrm{ha}{ }^{-1} \mathrm{~N} / \mathrm{P}_{2} \mathrm{O}_{5}$ fertilizerrateTable 3 . The grain yield advantage of $15.2 \%$ was obtained from $115 / 86 \mathrm{~kg} \mathrm{ha}^{-1} \mathrm{~N} / \mathrm{P}_{2} \mathrm{O}_{5}$ when compared to $69 / 52 \mathrm{~kg} \mathrm{ha}{ }^{-1} \mathrm{~N} / \mathrm{P}_{2} \mathrm{O}_{5}$ fertilizerrate. The responses of maize grain yield to increased NP fertilizer application rates were simulated via a linear regression model, at four densities over two years Figure 3. The result indicated as NP fertilizer rate increased the grain yield was increased and vice versa. Reduction of grain yield might be due to nutritional imbalance and deficiency of certain important plant growth elements at various important growth stages and also due to reduced leaf area development resulting in lesser radiation interception and, consequently, low efficiency in the conversion of solar radiation. The higher doses of chemical fertilizers increased grain yield as nutrients are the main driving force to produce high yield of maize [37].It is clear from the result that grain yield increased in response to increasing rate of NP fertilizer application possibly due to higher number of ears per plant.These increase the nutrients in the soil and modification of soil environments that resulted in better vegetative growth which in turn enabled the crop to produce greater photo-assimilate. The $\mathrm{N}$ has synergistic effects on growth and yield attributes resulting in greater translocation of photosynthates from source to sink, beneficial effect on physiological process, plant metabolism, growth and it is the major ingredient of proteins, enzymes, amino acids, amides and nucleic acids [38] and there by leading to higher grain yield. The $\mathrm{P}$ supply is particularly important for stimulating early root formation and growth, functions in plant macromolecular structures as a component of nucleic acids and phospholipids, with crucial roles in energy metabolism, participation in signal transduction path ways via phosphorylation and controlling key enzyme reactions [39]. 

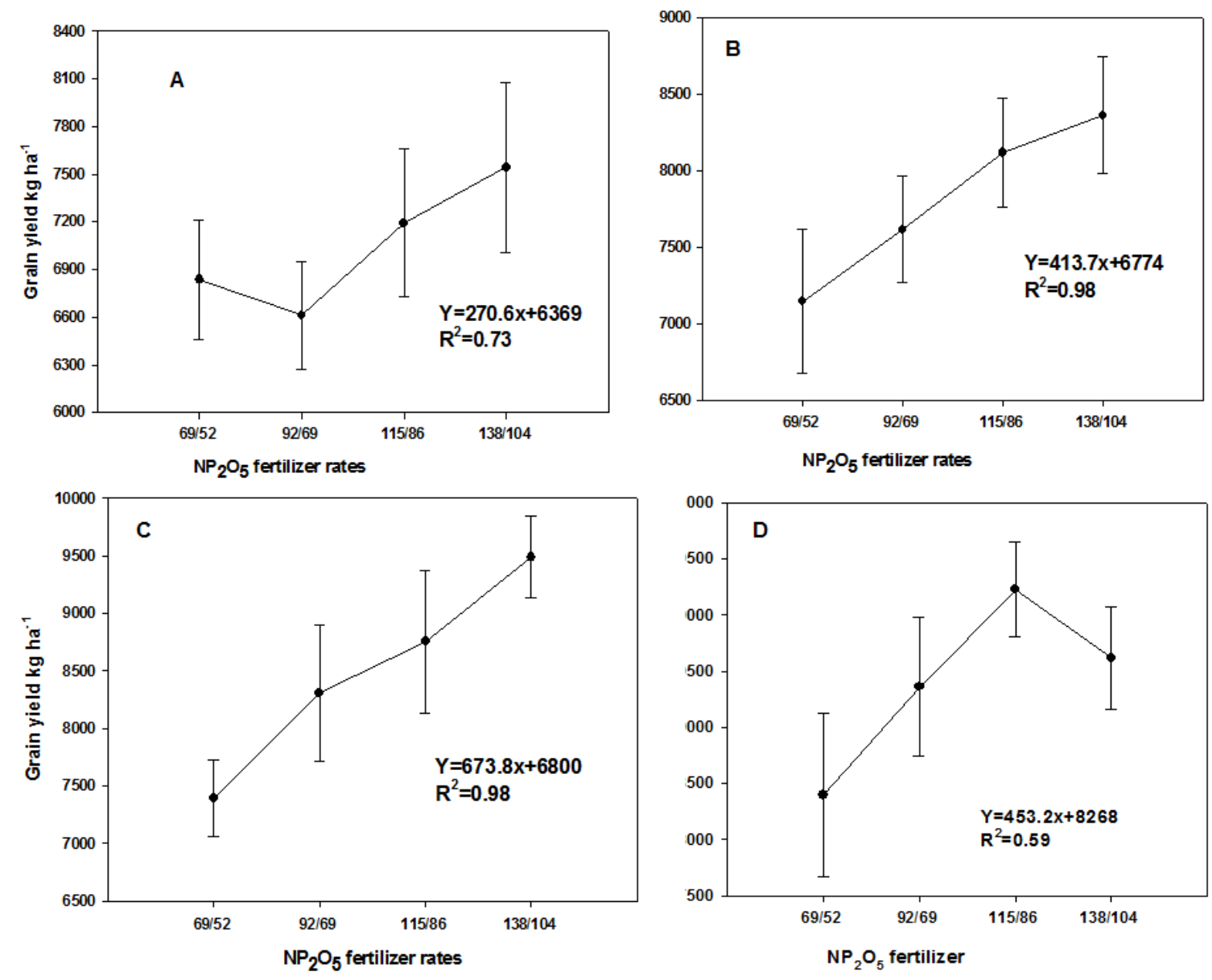

Figure-3. Maize grain yields as a function of NP application rate for four plant population densities over the year study. Planting densities were 44,444 (75x30cm), 53,333 (75x25cm), 66,667 $(75 \times 20 \mathrm{~cm})$ and 88,888 $(75 \times 15 \mathrm{~cm})$ in panels A-D respectively.

\subsection{Aboveground Biomass Yield}

The significant higher above ground biomass was recorded during the 2015 main cropping season than 2016 cropping season. The maximum above ground biomass 19.90 ton ha ${ }^{-1}$ was recorded from plant population density of 88,888 plants ha $^{-1}(75 \times 15 \mathrm{~cm})$ while, the minimum above ground biomass yield was obtained from plant population density of 44,444 plants ha $^{-1}(75 \times 30 \mathrm{~cm})$ Table 3 . The result indicates that as plant population density increased up 88,888 plants ha $^{-1}$ the above ground biomass linearly increased and vice versa. It was increased by $33.3 \%$ by planting the highest plant population rate than 44,444 plants ha ${ }^{-1}$. The result showed that biological yield was increased by increasing plant density due to high grain yield, number of ears per plant and plant height in the treatment of high plant population density of 88,888 plants ha ${ }^{-1}(75 \times 15 \mathrm{~cm})$ and low biomass yield was obtained in the treatment of lower plant population density 44,444 plants ha ${ }^{-1}(75 \times 30 \mathrm{~cm})$. The aboveground biomass yield was decreased in wider spacing due to minimum plant height and decreased ability of plants for capturing resources which was reflected as evident in their decreased biomass production. These results were in agreement with Bullock, et al. [40] who reported that narrow row spacing made more efficient use of available light and shaded the surface soil more completely during the early part of the growing season while the soil is still moist and therefore, narrow row spacing are more effective in producing biomass.

\subsection{Harvest Index}

The harvest index was not significantly $(\mathrm{P}>0.05)$ affected by cropping season, plant population density and NP fertilizer rate. But, the gained data was in the acceptable range of $0.4-0.6$ for maize [41].

\subsection{Economic Analysis}

The official prices of chemical fertilizer (NPS=13.5 birr kg-1) and urea $\left(10 \mathrm{birr} \mathrm{kg}^{-1}\right)$ were calculated based on stock sale prices of OmonadaFarmers Cooperative in May, 2015 and 2016. The sale of grain maize at Omonada open market average price was 4.6 ETB kg-1 in January, 2016 and 2017.The cost of labor spent on chemical fertilizer application and transport, seed planting and purchase were also used for partial budget analysis. The cost of application and transport of fertilizer was taken to be 15 birr $100 \mathrm{~kg}^{-1}$. Grain yield was adjusted by $10 \%$ for management difference to reflect the difference between the experimental yield and the yield that farmers could expect from the same treatment $[25,42]$.

The dominance analysis procedure as detailed in CIMMYT [25] was used to select potentially profitable treatments. Dominance analysis led to the selection of treatments ranked in increasing order of total variable costs Table 5. For each pair of ranked treatments, the percent marginal rate of return (MRR) was calculated. The MRR (\%) between any pair of un-dominated treatments were the return per unit of investment in chemical fertilizer and plant population density. It was calculated by dividing the change in net benefit to the change in variable costs. $100 \%$ MRR means for every 1 birr invested in different cost of fertilizer and maize seed, farmers can expect to recover 1 birr and obtain an additional 1 birr [25]. 
Table-3. Main effects of intra row spacing, NP fertilizer rates and year on growth and yield component of BHQPY-545 at Jimma zone, Omonadaworeda over 2015 and 2016 cropping season.

\begin{tabular}{|c|c|c|c|c|c|}
\hline Treatment & Plant height $(\mathrm{cm})$ & lodging \% & Grain yield $\left(\mathrm{t} \mathrm{ha}^{-1}\right)$ & $\mathrm{AGB}\left(\mathrm{t} \mathrm{ha}^{-1}\right)$ & HI \\
\hline \multicolumn{6}{|l|}{ Year } \\
\hline 2015 & $228 \mathrm{~b}$ & $28.4 \mathrm{a}$ & $8950 a$ & $18.75 \mathrm{a}$ & 0.48 \\
\hline 2016 & $257 \mathrm{a}$ & $18.4 \mathrm{~b}$ & $7421 \mathrm{~b}$ & $15.85 \mathrm{~b}$ & 0.47 \\
\hline LSD (0.05) & 4.398 & 4.159 & 486.830 & 0.833 & 0.015 \\
\hline F-test & *** & *** & ** & *** & NS \\
\hline \multicolumn{6}{|c|}{ Plant population density $\left(\right.$ plantha $\left.^{-1}\right)$} \\
\hline $88,888(75 \times 15 \mathrm{~cm})$ & $247 \mathrm{a}$ & 21.0 & $9401 \mathrm{a}$ & $19.90 \mathrm{a}$ & 0.47 \\
\hline $66,667(75 \times 20 \mathrm{~cm})$ & $243 \mathrm{a}$ & 20.6 & $8485 \mathrm{~b}$ & $18.00 \mathrm{~b}$ & 0.47 \\
\hline $53,333(75 \times 25 \mathrm{~cm})$ & $243 \mathrm{a}$ & 26.6 & $7809 \mathrm{~b}$ & $16.37 \mathrm{c}$ & 0.48 \\
\hline $44,444(75 \times 30 \mathrm{~cm})$ & $237 \mathrm{~b}$ & 25.3 & $7046 \mathrm{c}$ & $14.93 \mathrm{~d}$ & 0.47 \\
\hline $\mathrm{LSD}(0.05)$ & 6.11 & 13.86 & 727.7 & 0.474 & 0.046 \\
\hline $\mathrm{CV}(\%)$ & 6.36 & 38.9 & 20.87 & 16.89 & 10.81 \\
\hline F-test & * & NS & *** & *** & $\mathrm{NS}$ \\
\hline \multicolumn{6}{|c|}{$\mathbf{N} / \mathbf{P}_{2} \mathrm{O}_{5}$ Fertilizer rates $\left(\mathrm{kg} \mathrm{ha}^{-1}\right)$} \\
\hline $69 / 52$ & $235 \mathrm{c}$ & 22.0 & $7442 \mathrm{c}$ & $15.91 \mathrm{c}$ & 0.47 \\
\hline $92 / 69$ & $241 \mathrm{~b}$ & 22.4 & $7974 \mathrm{bc}$ & $17.05 \mathrm{bc}$ & 0.47 \\
\hline $115 / 86$ & $245 \mathrm{ab}$ & 24.2 & $8574 \mathrm{ab}$ & $17.91 \mathrm{ab}$ & 0.48 \\
\hline $138 / 104$ & $251 \mathrm{a}$ & 25.0 & $8752 \mathrm{a}$ & $18.33 \mathrm{a}$ & 0.48 \\
\hline LSD (0.05) & 6.22 & 5.88 & 688.5 & 1.178 & 0.021 \\
\hline $\mathrm{CV}(\%)$ & 3.87 & 40.5 & 13.61 & 4.22 & 15.19 \\
\hline F-test & *** & $\mathrm{NS}$ & *** & *** & $\mathrm{NS}$ \\
\hline
\end{tabular}

Note: $\mathrm{LSD}=$ Least Significant Difference; $\mathrm{CV}=$ Coefficient of Variation; NS=Non significant; HI= Harvest Index; AGB=Above Ground Biomass; Values followed by the same letter within a column are not significantly different at $\mathrm{P}<0.05$.

The highest net benefit 36,705.0 ETB ha-1 was obtained from plant population density of 88,888 plants ha-1 $\left(75^{*} 15 \mathrm{~cm}\right)$ with acceptable MRR 584.5\%. Whereas, the lowest net benefit 28,062 ETB ha-1 was obtained from the lower plant population density 44,444 plants ha-1Table 4 . Due to planting of 88,888 plants ha-1 $\left(75^{*} 15 \mathrm{~cm}\right)$, there was a net benefit increase by $30.8 \%\left(8,643 \mathrm{ETB} \mathrm{ha}^{-1}\right)$ when compared with that of lower plant population density 44,444 plants ha ${ }^{-1}\left(75^{*} 30 \mathrm{~cm}\right)$.

Table-4. Partial budget analyses of NP fertilizer rates and plant population density on grain yield of medium maturing maize variety QPYBH545 at Jimma

\begin{tabular}{|c|c|c|c|c|c|}
\hline $\begin{array}{l}\mathbf{N} / \mathbf{P}_{2} \mathrm{O}_{5} \\
\left(\mathrm{Kg} \mathrm{ha}^{-1}\right) \\
\end{array}$ & $\begin{array}{c}\text { GY } \\
\left(\mathrm{kg} \mathrm{ha}^{-1}\right) \\
\end{array}$ & $\begin{array}{l}\text { Adj.GY } \\
\left(\mathrm{kg} \mathrm{ha}^{-1}\right) \\
\end{array}$ & $\begin{array}{c}\text { GFB } \\
\left(\text { ETB ha }^{-1}\right) \\
\end{array}$ & $\begin{array}{c}\text { TVC } \\
\left(\text { ETB ha-1) }^{-1}\right.\end{array}$ & $\begin{array}{c}\text { NB } \\
\left(\mathrm{ETB} \mathrm{ha}^{-1}\right) \\
\end{array}$ \\
\hline $69 / 52$ & 7442.2 & 6698.0 & 30810.71 & 2933.6 & 27877.11 \\
\hline $92 / 69$ & 7973.6 & 7176.2 & 33010.7 & 3885.3 & 29125.4 \\
\hline $115 / 86$ & 8574.1 & 7716.7 & 35496.77 & 4827.5 & 30669.27 \\
\hline $138 / 104$ & 8751.6 & 7876.4 & 36231.62 & 5807.3 & 30424.32 \\
\hline \multicolumn{6}{|c|}{ Plant population density } \\
\hline $88888(75 * 15 \mathrm{~cm})$ & 9401.2 & 8461.1 & 38920.97 & 2216 & 36705.0 \\
\hline $66666\left(75^{*} 20 \mathrm{~cm}\right)$ & 8485.2 & 7636.7 & 35128.73 & 1662 & 33466.7 \\
\hline $53333(75 * 25 \mathrm{~cm})$ & 7809.2 & 7028.3 & 32330.09 & 1317.6 & 31012.5 \\
\hline $44444(75 * 30 \mathrm{~cm})$ & 7046 & 6341.4 & 29170.44 & 1108 & 28062.4 \\
\hline
\end{tabular}

Note: *GY $=$ Grain yield; GFB Gross field benefit; TCV $=$ Total cost that varied; NB $=$ Net benefit;

ETB $=$ Ethiopian Birr; Price of chemical fertilizer $=13.5 \mathrm{birr} \mathrm{kg}^{-1}$; Price of Urea $=10$ birr kg-1; Wage rate $=30$ Birr man-day ${ }^{-1}$; Retail price of grain $=4.6 \mathrm{birr}^{-1}$ $\mathrm{kg}^{-1}$.

Table-5. Partial budget with dominance analysis and MRR (\%) of NP fertilizer and plant population density of medium maturing maize variety QPYBH545 at Jimma zone in 2015-2016.

\begin{tabular}{|c|c|c|c|c|c|c|c|}
\hline $\begin{array}{l}\mathbf{N} / \mathbf{P}_{2} \mathbf{O}_{5} \\
\left(\mathbf{K g ~ h a}^{-1}\right) \\
\end{array}$ & $\begin{array}{c}\text { GY } \\
\left(\mathrm{kg} \mathrm{ha}^{-1}\right) \\
\end{array}$ & $\begin{array}{l}\text { Adj.GY } \\
\left(\mathbf{k g ~ h a} \mathbf{h a}^{-1}\right)\end{array}$ & $\begin{array}{c}\text { GFB } \\
\left(\text { ETB ha-1 }^{-1}\right)\end{array}$ & $\begin{array}{c}\text { TVC } \\
\left(\text { ETB ha }^{-1}\right)\end{array}$ & $\begin{array}{c}\text { NB } \\
(\text { ETB ha-1) }\end{array}$ & $\begin{array}{l}\text { Domi } \\
\text { nance }\end{array}$ & $\begin{array}{c}\text { MRR } \\
(\%)\end{array}$ \\
\hline $69 / 52$ & 7442.2 & 6698.0 & 30810.71 & 2933.6 & 27877.11 & --- & -- \\
\hline $92 / 69$ & 7973.6 & 7176.2 & 33010.7 & 3885.3 & 29125.4 & UD & 131.2 \\
\hline $115 / 86$ & 8574.1 & 7716.7 & 35496.77 & 4827.5 & 30669.27 & UD & 163.9 \\
\hline $138 / 104$ & 8751.6 & 7876.4 & 36231.62 & 5807.3 & 30424.32 & $\mathrm{D}$ & -- \\
\hline \multicolumn{8}{|l|}{ Population Density } \\
\hline $44444(75 * 30 \mathrm{~cm})$ & 7046.0 & 6341.4 & 29170.44 & 1108.0 & 28062.4 & $\begin{array}{c}-- \\
\end{array}$ & -- \\
\hline $53333(75 * 25 \mathrm{~cm})$ & 7809.2 & 7028.3 & 32330.09 & 1317.6 & 31012.5 & UD & 1407.5 \\
\hline $66666(75 * 20 \mathrm{~cm})$ & 8485.2 & 7636.7 & 35128.73 & 1662.0 & 33466.7 & UD & 712.6 \\
\hline $88888(75 * 15 \mathrm{~cm})$ & 9401.2 & 8461.1 & 38920.97 & 2216.0 & 36705.0 & UD & 584.5 \\
\hline
\end{tabular}

Regarding the effect of NP fertilizer rates the highest net benefit 30,669ETB ha-1 was obtained from $115 / 86 \mathrm{~kg}$ $\mathrm{ha}^{-1} \mathrm{~N} / \mathrm{P}_{2} \mathrm{O}_{5}$ fertilizer with acceptable MRR $163.9 \%$. Whereas, the lowest net benefit $\left(27,877 \mathrm{ETB}^{-1} \mathrm{ha}^{-1}\right)$ was obtained from the lower NP fertilizer rate $69 / 52 \mathrm{~kg} \mathrm{ha}^{-1} \mathrm{~N} / \mathrm{P}_{2} \mathrm{O}_{5}$ Table 5 and Figure4. Due to application of 115/86 $\mathrm{kg} \mathrm{ha}^{-1} \mathrm{~N} / \mathrm{P}_{2} \mathrm{O}_{5}$ fertilizer, there was net benefit increase by $10 \%(2792 \mathrm{ETB})$ when compared with $69 / 52 \mathrm{~kg} \mathrm{ha}^{-1}$ $\mathrm{N} / \mathrm{P}_{2} \mathrm{O}_{5}$ fertilizer. 


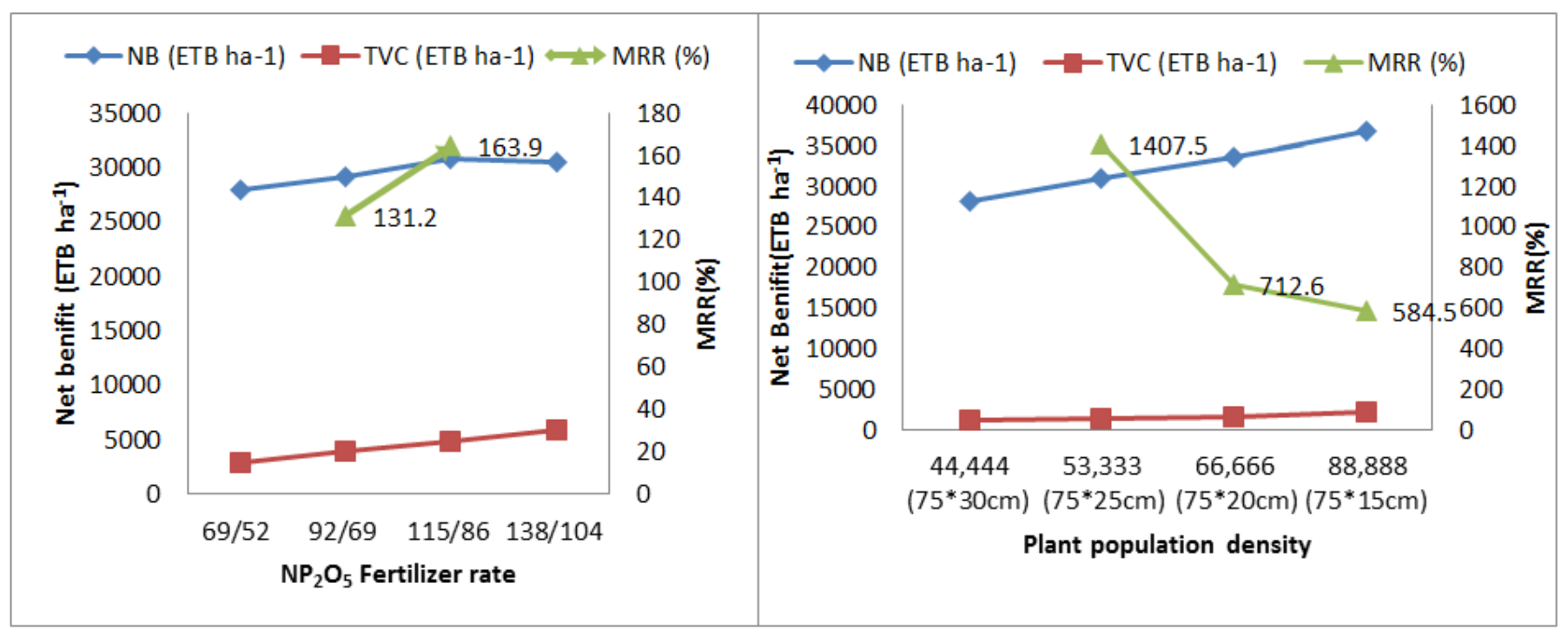

Figure-4. Total variable cost, net benefit and MRR \% of NP fertilizer rate and plant population density rate of QPYBH545 maize variety at Jimma zone in 2016 and 2017 cropping season.

Market prices are ever changing and as such a recalculation of the partial budget using a set of likely future prices (i.e., sensitivity analysis) was essential to identify treatments which may likely remain stable and sustain satisfactory returns for farmers despite price fluctuations. The sensitivity analysis study indicates an increase in the field price of the total variable costs, and a fall in the price of maize grain, which represented a price variation of $15 \%$.

The price changes are realistic under market conditions prevailing at Jimma area which were above the minimum acceptable MRR of $100 \%$ for application of $115 / 86 \mathrm{NP}_{2} \mathrm{O}_{5}$ fertilizer.

Concerning plant population density 88,888 plants ha-1 $\left(75^{*} 15 \mathrm{~cm}\right), 66,666$ plants ha-1 $\left(75^{*} 20 \mathrm{~cm}\right)$ and 53,333 plants ha-1 $\left(75^{*} 25 \mathrm{~cm}\right)$ are realistic which were above the minimum acceptable MRR of $100 \%$ Table 6 .

Table-6. Sensitivity analysis of maize production based on a $15 \%$ rise in total cost and maizeprice of gross field benefit fall.

\begin{tabular}{|c|c|c|c|c|c|}
\hline $\mathbf{N} / \mathbf{P}_{2} \mathbf{O}_{5}$ Fertilizer & TVC (ETB ha') & NB $\left(\right.$ ETB ha' ha $^{-1}$ & Raised cost & Raised benefit & MRR (\%) \\
\hline $69 / 52$ & 3373.64 & 23695.54 & ---- & ---- & --- \\
\hline $92 / 69$ & 4468.095 & 24756.59 & 1094.46 & 1061.05 & 96.95 \\
\hline $115 / 86$ & 5551.625 & 26068.88 & 1083.53 & 1312.29 & 121.11 \\
\hline \multicolumn{6}{|l|}{ Population density } \\
\hline $44444(75 * 30 \mathrm{~cm})$ & 1274.2 & 23853.1 & --- & $\begin{array}{ll}--- \\
\end{array}$ & $\begin{array}{ll}--- \\
\end{array}$ \\
\hline $53333(75 * 25 \mathrm{~cm})$ & 1515.24 & 26360.6 & 241.04 & 2507.54 & 1040.30 \\
\hline $66666(75 * 20 \mathrm{~cm})$ & 1911.3 & 28446.7 & 396.06 & 2086.10 & 526.71 \\
\hline $88888(75 * 15 \mathrm{~cm})$ & 2548.4 & 31199.2 & 637.10 & 2752.50 & 432.04 \\
\hline
\end{tabular}

return; Price of chemical fertilizer $=13.5 \mathrm{birr} \mathrm{kg}^{-1}$; Price of Urea $=10 \mathrm{birr} \mathrm{kg}^{-1}$, Wage rate $=30$ Birr man-day ${ }^{-1}$; Retail price of grain $=6 \mathrm{birr} \mathrm{kg}^{-1}$.

\section{Conclusion and Recommendation}

Lately innovated maize varieties such as quality protein maize (QPM) versions vary in stature and leaf arrangements from known normal maize varieties. These variations in morphology may lead to different planting density to reach at their at maximum yield potentials. In view of this, plant population density study on QPM hybrid (BHQPY 545) was proposed with two objectives to maximize yield potential and to help small holder farmers to feed their families with high protein diet. Accordingly, rigorous research efforts were made on research station fields of JimmaJimma Research Center (Melko and Mettu) and on farmers field in vicinity of the center for three cropping seasons. Summary of results from across seasons and sites indicated that at highest plant population density, grain and biomass yields were significantly increased. Similarly, the higher fertilizer doses produced significantly higher biomass and grain yields. To increase certainty and further use of optimum plant density evaluation criteria was set by farmers and subjected to choose or reject any density not technically appropriate. Thus, for the future production of maize hybrid, BHQPY545 in Omonadawareda and adjacent waredas with similar agro-ecologies, a plant population density of 88,888 plant ha $^{-1}(75 \times 15 \mathrm{~cm}$ a plant hill-1 or $75 \times 30 \mathrm{~cm}$ two plants hill-1 $^{-1}$ ) in complement with NP fertilizer rate of $115 / 86 \mathrm{~kg} \mathrm{ha}^{-1}$ can be recommended.

\section{References}

[1] FAOSTAT, "Statistical database of the food and agriculture organization of the United Nations. Retrieved from faostat3.fao.org/browse/Q/QC/E," 2016.

[2] CSA (Central Statistical Agency), Agricultural sample survey: Report on area and production of crops vol. 1. Addis Ababa, Ethiopia: Statistical Bulletin, 2017.

[3] T. R. Shah, K. Prasad, and P. Kumar, Studies on physicochemical and functional characteristics of asparagus bean flour and maize flour. In: Conceptual frame work and innovations in agro-ecology and food sciences. New Delhi: Krishi Sanskriti Publications, 2015.

[4] K. Mbuya, K. Nkongolo, and A. Kalonji-Mbuyi, "Nutritional analysis of quality protein maize varieties selected for agronomic characteristics in a breeding program," International Journal of Plant Breeding and Genetics, vol. 5, pp. 317-327, 2011. Available at: https://doi.org/10.3923/ijpbg.2011.317.327.

[5] A. Bisht, A. Bhatnagar, M. Pal, and V. Singh, "Growth dynamics, productivity and economics of quality protein maize (Zea mays L.) under varying plant density and nutrient management practices," Madras Agricultural Journal, vol. 99, pp. 73-76, 2012.

[6] B. S. Vivek, A. F. Krivanek, N. Palacios-Rojas, S. Twumasi-Afriyie, and A. O. Diallo, Breeding quality protein maize (QPM): Protocols for developing QPM cultivars. Mexico: CIMMYT, 2008.

[7] K. Goulding, S. Jarvis, and A. Whitmore, "Optimizing nutrient management for farm systems," Philosophical Transactions of the Royal Society B: Biological Sciences, vol. 363, pp. 667-680, 2008. Available at: https://doi.org/10.1098/rstb.2007.2177. 
A. Abebayehu, E. Elias, and J. Diels, "Comparative analysis of soil nutrient balance at farm level: A case study in Jimma Zone, Ethiopia," International Journal of Soil Science, vol. 6, pp. 259-266, 2011. Available at: https://doi.org/10.3923/ijss.2011.259.266. B. Vanlauwe, A. Bationo, J. Chianu, K. E. Giller, R. Merckx, U. Mokwunye, O. Ohiokpehai, P. Pypers, R. Tabo, and K. D. Shepherd, "Integrated soil fertility management: Operational definition and consequences for implementation and dissemination," Outlook on Agriculture, vol. 39, pp. 17-24, 2010. Available at: https://doi.org/10.5367/000000010791169998.

J. O. S. Kogbe and J. A. Adediran, "Influence of nitrogen, phosphorus and potassium application on the yield of maize in the savanna zone of Nigeria," African Journal of Biotechnology, vol. 2, pp. 345-349, $2003 . \quad$ Available at: https://doi.org/10.5897/ajb2003.000-1071.

R. O. Onasanya, O. P. Aiyelari, A. Onasanya, S. Oikeh, F. E. Nwilene, and O. O. Oyelakin, "Growth and yield response of maize (Zea mays L.) to different rates of nitrogen and phosphorus fertilizers in Southern Nigeria," World Journal of Agricultural Sciences, vol. 5, pp. 400-407, 2009 .

M. Ayub, M. Nadeem, M. Sharar, and N. Mahmood, "Response of maize (Zea mays L.) fodder to different levels of nitrogen and phosphorus," Asian Journal of Plant Sciences, vol. 1, pp. 352-355, 2002. Available at: https://doi.org/10.3923/ajps.2002.352.354.

P. Yan, J. Pan, W. Zhang, J. Shi, X. Chen, and Z. Cui, "A high plant density reduces the ability of maize to use soil nitrogen," PloS one, vol. 12, pp. e0172717-e0172717, 2017. Available at: https://doi.org/10.1371/journal.pone.0172717.

F. Bavec and M. Bavec, "Effects of plant population on leaf area index, cob characteristics and grain yield of early maturing maize cultivars (FAO 100-400)," European Journal of Agronomy, vol. 16, pp. 151-159, 2002. Available at: https://doi.org/10.1016/s11610301(01)00126-5.

N. H. Batjes, "Aglobal data set of soil pH properties," Technical Paper No. 27, International Soil Reference and Information Centre (ISRIC), Wageningen, 1995

N. Brady and R. R. Weil, Nature and properties of soils, 14th ed. Upper Saddle River: Prentice Hall, 2008.

D. Berhanu, "A survey of studies conducted about soil resources appraisal and evaluation for rural development in Ethiopia," ed Addis Ababa: Ethiopia Institute of Agricultural Research, 1980, p. 70.

T. Tekalign, "Soil, plant, water, fertilizer, animal manure and compost analysis," Working Document No. 13. ILR Center for Africa, Addis Ababa, Ethiopia, 1991.

M. Tekalign and I. Haque, "Phosphorus status of some Ethiopian soils, II. Forms and distribution of inorganic phosphates and their relation to available phosphorus," Tropical Agriculture, vol. 68, pp. 2-8, 1991.

H. F. Murphy, "A report on the fertility status and other data on some soils of Ethiopia," Experimental Station Bulletin No. 44. Oklahoma State University, p. $551,1968$.

J. Bremner, "Nitrogen-total," Methods of Soil Analysis: Part 3 Chemical Methods, vol. 5, pp. 1085-1121, 1996.

M. L. Jackson, Estimation of phosphorus content: Soil chemical analysis. New Delhi (India): Printer Hall, 1973.

N. Brady and R. R. Weil, The nature and properties of soils, 13th ed. New Jersey, USA: Prentince Hall, 2002.

C. M. Donald, "In search of yield," Journal of Australian Institute of Agricultural Science, vol. 28, pp. 171-178, 1962.

CIMMYT, From agronomic data to farmer recommendations: An economics training manual. Mexico, D.F: Completely Revised Edition, 1988.

S. T. H. Shah, M. S. I. Zamir, M. Waseem, A. Ali, M. Tahir, and W. B. Khalid, "Growth and yield response of maize (Zea mays L.) to organic and inorganic sources of nitrogen," Pakistan Journal of Life and Social Sciences, vol. 7, pp. 108-111, 2009.

U. R. Sangakkara, P. S. R. D. Bandaranayake, J. N. Gajanayake, and P. Stamp, "Plant populations and yield of rainfed maize grown in wet and dry seasons of the tropics," Maydica, vol. 49, pp. 83-88, 2004.

A. Hassan, "Effect of plant population density on yield and yield components of eight Egyptian maize hybrids," Bulletin of Faculty of Agriculture, University of Cairo, vol. 51, pp. 1-16, 2000

C. Rao, K. Singh, and M. Ali, "Sulphur: A key nutrient for higher pulse production," Fertilizer News, vol. 46, pp. 37-50, 2001. F. Adekayode and M. Ogunkoya, "Effect of quantity and placement distances of inorganic 15-15-15 fertilizer in improving soil fertility status and the performance and yield of maize in a tropical rain forest zone of Nigeria," Journal of Soil Science and Environmental Management, vol. 1, pp. 155-163, 2010.

A. Kumar, R. C. Guatam, S. Ranbir, and K. S. Rana, "Growth, yield and economics of maize- wheat cropping sequence as influenced by integrated nutrient management," Indian Journal of Agricultural Science, vol. 75, pp. 709-71 1, 2005.

T. Adefris, W. Dagne, T. Abraham, T. Birhanu, B. Kassahun, F. Dennis, and B. M. Prasanna, Quality protein maize (QPM): A guide to the technology and its promotion in Ethiopia. Addis Ababa, Ethiopia: CIMMYT, 2015.

A. Hashemi-Dezfouli and S. J. Herbert, "Intensifying plant density response of corn with artificial shade," Agronomy Journal, vol. 84, pp. 547-551, 1992. Available at: https://doi.org/10.2134/agronj 1992.00021962008400040001x.

D. Singh and V. Nepalia, "Influence of integrated nutrient management on quality protein maize (Zea mays) productivity and soils of Southern Rajasthan," Indian Journal of Agricultural Sciences, vol. 79, pp. 1020-1022, 2009.

Y. Emam, "Sensitivity of grain yield components to plant population density in non-prolific maize (Zea mays) hybrids," Indian Journal of Agricultural Science, vol. 71, pp. 367-370, 2001

D. E. Farnham, "Row spacing, plant density, and hybrid effects on corn grain yield and moisture," Agronomy Journal, vol. 93, pp. 1049-1053, 2001. Available at: https://doi.org/10.2134/agronj2001.9351049x.

S. Nivong, T. Attanandana, and R. Yost, "Nitrogen fertilizer response of maize on some important soils from DSSAT software prediction," Kasetsart (Natural Science), vol. 41, pp. 21-27, 2007.

J. Y. Yayock, G. Lombin, and J. J. Owonubi, Crop science and production in warm climates. London: Macmillan, 1988.

P. Marschner, Rhizosphere biology. In: Marschner's mineral nutrition of higher plants, 3rd ed.: Elsevier, 2012.

D. Bullock, S. Khan, and A. Rayburn, "Soybean yield response to narrow rows is largely due to enhanced early growth," Crop Science, vol. 38, pp. 1011-1016, 1998. Available at: https://doi.org/10.2135/cropsci1998.0011183x003800040021x. N. V. Hue, Sewage sludge. In: Jack E. Rechcigl (Eds.), Soil amendments and environmental quality. London: Lewis, 1995.

A. Getachew and B. Taye, "On-farm integrated soil fertility management in wheat on Nitisols of central Ethiopian highlands," Ethiopian Journal of Natural Resources, vol. 7, pp. 141-155, 2005. 